\title{
The Localization of Streptococcal Group and Type Antigens: an Electron-microscopic Study Using Ferritin-labelled Antisera
}

\author{
By J. H. J. HUIS IN 'T VELD AND W. H. LINSSEN \\ Department of Preventive Dentistry and Centre for Electronmicroscopy, \\ Medical Faculty, State University of Utrecht, Catharijnesingel 59, \\ Utrecht, The Netherlands
}

(Received I4 July I972; revised I3 October 1972)

SUMMAR Y

Electron microscopy was used to study streptococci carrying the carbohydrate antigens $z_{3}$ as a group antigen and III as a type antigen (strain $z_{3}$ III) and a mutant carrying only the group antigen (strain $z_{3}$ ). The cell-envelope of $z_{3}$ III bacteria seems to consist of: (i) a thin layer, representing the membrane; and (ii) a thicker layer probably identical with the mucopeptide and the polysaccharide antigens. Staining of bacteria with ferritin-labelled antisera showed that: (i) type antigens located on the outermost layer of the streptococcal cell-envelope seem to be capsule-like materials; (ii) group antigens are located more to the inside of the streptococcal envelope.

\section{INTRODUCTION}

When a streptococcal strain carrying a group and type antigen is injected into rabbits, antibodies only directed against the type antigen are obtained (Ottens \& Winkler, 1962). This suggests a localization of the type antigen on the outer part of the streptococcal wall. Staining of bacteria with fluorescent antisera gave results confirming this idea (Willers, Deddish \& Slade, I968).

A mutant strain $\left(\mathrm{z}_{3}\right)$ lacking type antigens contained less carbohydrate in the walls than the parent strain $\left(\mathrm{z}_{3} \mathrm{III}\right)$. It also differs in some physiological properties (J. Huis in 't Veld $\& \mathbf{J}$. Willers, to be published). It is of interest to know if this lower carbohydrate content is correlated with differences in the wall ultrastructure of these strains. In order to localize the group and type antigens within the streptococcal envelope ferritin-labelled antigroup and antitype sera were prepared.

Electron-microscopic studies with ferritin-labelled antigroup and antitype sera indicated the localization of these antigens and produced further information on the wall structure.

\section{METHODS}

Bacterial strains. Streptococcus $\mathrm{z}_{3} \mathrm{III}$ and FIII (NCTC8037) were obtained from Dr de Moor (National Institute of Public Health, Bilthoven, The Netherlands). A mutant strain $\mathrm{z}_{3}$ lacked the type III antigen (Willers \& Alderkamp, 1967).

Culture conditions. Organisms were grown for $30 \mathrm{~h}$ at $37^{\circ} \mathrm{C}$ in Todd-Hewitt broth containing in $\mathrm{g} / \mathrm{l}$ : Todd-Hewitt broth (Difco), I5; glucose, 4 ; and sodium bicarbonate, 3. The bacteria were collected by centrifugation, washed three times with cold saline and used immediately for electron microscopy.

Preparation of ferritin-labelled antisera. Rabbit antigroup (anti- $\mathrm{Z}_{3}$ ) and antitype (anti-III) 
sera were obtained from Mr M. de Reuver, Department of Immunochemistry, Laboratory for Microbiology, State University of Utrecht. The anti-III serum was prepared with FIII bacteria as the immunogen, to avoid any possibility of the production of anti- $z_{3}$ antibodies in the antitype serum. The anti- $z_{3}$ serum was prepared with the mutant strain $z_{3}$ as the immunogen.

To $50 \mathrm{ml}$ of antistreptococcal serum, $30 \mathrm{ml}$ of a $75.5 \%$ (w/v) solution of $\left(\mathrm{NH}_{4}\right)_{2} \mathrm{SO}_{4}$ was added. After standing $\mathrm{I} 6 \mathrm{~h}$ at $4{ }^{\circ} \mathrm{C}$ the precipitate (mainly Ig G) was collected by centrifugation and dissolved in as little distilled water as possible. This solution was dialysed against $0.0 \mathrm{I} 5 \mathrm{M}$-sodium sulphate, $\mathrm{pH} 8 \cdot 0$, till no $\mathrm{NH}_{4}{ }^{+}$could be detected in the diffusate. The crude Ig G solution was applied to a DEAE cellulose column equilibrated with $0.015 \mathrm{M}$ $\mathrm{Na}_{2} \mathrm{HPO}_{4}$ buffer, $\mathrm{pH} 8 \cdot 0$. Elution occurred with the same buffer and the absorption of the eluate was measured at $280 \mathrm{~nm}$. The eluate of the first peak containing Ig G was collected and concentrated with lyphogel (Gelman, Hauksley, Lancing, Sussex) to about $20 \mathrm{mg}$ protein $/ \mathrm{ml}$. The ferritin coupling was performed according to a method of Sri Ram, Tawde, Pierce \& Midgley (I963) modified by Linssen (I97I). To I $\mathrm{ml}$ of Ig G solution, $0.6 \mathrm{ml}$ of a I0\% ferritin solution (Mann Research Laboratories) was added. The $\mathrm{pH}$ was raised to 10.5 at $0{ }^{\circ} \mathrm{C}$ with cold $5 \%(\mathrm{w} / \mathrm{v}) \mathrm{Na}_{2} \mathrm{CO}_{3}$. A cold freshly prepared solution of $p$ - $p$-difluoro- $m-m$ dinitro phenyl sulphon(FNPS) in $14 \mathrm{ml}$ dry propanol-free acetone $(5 \mathrm{mg}$ FNPS $/ \mathrm{ml})$ was added dropwise with stirring. The solution was stirred slowly for $24 \mathrm{~h}$ at $4{ }^{\circ} \mathrm{C}$, dialysed for 3 days against $0.2 \mathrm{M}-\mathrm{NaCl}$ and concentrated with lyphogel to approx. $0.5 \%$ protein.

The degree of coupling was checked with the Ouchterlony technique and with immuneelectrophoresis (Linssen, 1971).

\section{Electron microscopy}

I. For morphological studies the bacteria were fixed in $\mathrm{I} \% \mathrm{OsO}_{4}($ Kellenberger, Ryter \& Séchaud, 1958 ) or $2 \%$ glutaraldehyde, dehydrated in ethanol and embedded in Epon 8I2.

2. For immunoferritin experiments on whole bacteria the bacteria were fixed in a solution containing I \% glutaraldehyde and I \% formaldehyde in $0.07 \mathrm{M}$-phosphate buffer, $\mathrm{pH} 7.5$, for $30 \mathrm{~min}$, washed three times with phosphate buffer and incubated for $20 \mathrm{~h}$ with the ferritin-labelled antibodies at $4{ }^{\circ} \mathrm{C}$. The organisms were washed three times for $6 \mathrm{~h}$ with the same phosphate buffer and postfixed with $2 \%$ glutaraldehyde. After dehydration with ethanol, they also were embedded in Epon 8I 2 .

3. For studying the immunoferritin technique on ultrathin sections, the bacteria were fixed as under 2, dehydrated in increasing concentrations of glycolmethacrylate (GMA) according to Leduc \& Holt (1965) and embedded in GMA, containing $5 \%$ diphenyl benzene (Linssen, 1971).

Ultrathin sections of the embedded bacteria were incubated with Io $\mu \mathrm{l}$ of ferritin-labelled antibody $(0.5 \%$ protein) in a trough (depth $9 \mathrm{~mm}$, diam. $12 \mathrm{~mm}$ ) filled to the brim with $0 \cdot$ I $\mathrm{M}$-phosphate buffer, $\mathrm{pH} 7 \cdot 6$. The incubation mixture was slowly stirred at room temperature with a magnetic stirrer. After $2 \mathrm{~h}$ of incubation, sections were exhaustively washed with $0 . \mathrm{I}$ M-phosphate buffer, $\mathrm{pH} 7 \cdot 6$, and distilled water; to avoid non-specific binding of the immunoferritin complex to DNA and RNA in some cases the sections were pre-incubated with apoferritin (Linssen, 197I). For control and blocking experiments ferritin-labelled nonspecific rabbit $\gamma$-globulin and unlabelled antitype III (respectively) were used.

4. Sections of the embedded bacteria were prepared with a LKB ultramicrotome. Some of the sections were stained with lead citrate or uranyl acetate. 
RESULTS

Morphology. The wall of the mutant strain $\mathrm{z}_{3}$ had a thinner and a less electron-dense appearance as compared with the parent strain (Fig. I). The envelope of $\mathrm{z}_{3} \mathrm{III}$ seemed to consist of: (i) a thin distinct layer representing the membrane; (ii) a less electron-dense layer without specific structural features, probably representing the mucopeptide together with the wall polysaccharides; and (iii) an electron-dense layer at the site where the cross wall was in the process of dividing the organism into two daughter cocci (Fig. 2). This latter could only be visualized at sites where the septum was forming.

Immunoferritin experiments. To get more information about the localization of the group $\left(Z_{3}\right)$ and type (III) antigen, organisms were stained with specific ferritin-labelled anti- $Z_{3}$ and anti-III sera. In mutant strain $z_{3}$ stained with anti- $z_{3}$ (Fig. 3 ) the group antigen $z_{3}$ appeared as a thin layer, located close to the underlying mucopeptide. In a broken organism on the right the ferritin-labelled anti- $z_{3}$ serum had reacted with the inner part of the envelope, i.e. the site where the cytoplasmic membrane was located.

The parent strain $z_{3} I I I$ had no visible reaction with the ferritin-labelled anti- $z_{3}$ serum (Fig. 4). Only a mutant strain lacking type III antigens gave a positive reaction with anti- $Z_{3}$ serum, while ferritin-labelled antitype III serum did not react with the mutant strain $z_{3}$ (Fig. 5). The parent strain reacted strongly with this serum (Fig. 6). If whole bacteria are reacted with the antibodies, only the outer layer of the capsule appeared to consist of type III antigen. However, when ferritin-labelled anti-III serum was applied to a section the whole envelope of these bacteria consisted of material which reacted (Fig. 7). Type III antigen was present in abundance throughout the capsule. A positive reaction could also be seen at some sites within the cytoplasmic matrix.

Non-specific binding of ferritin molecules with DNA and RNA occurred since pre-incubation of the section with apoferritin prevented this non-specific binding almost completely (Fig. 8). Possible sites of antigen synthesis or storage near the cytoplasmic membrane still showed their strong positive reaction with the labelled anti-III serum.

The specificity of the ferritin-labelled antisera was demonstrated in blocking experiments (Fig. 9). Pre-incubation of the section with unlabelled antitype serum diminished the number of attached ferritin particles considerably, as the combining sites of the type III antigens were already occupied by non-ferritin-labelled antibodies. The specificity of the ferritin-labelled antisera was also confirmed by incubating bacteria with ferritin-labelled non-specific rabbit $\gamma$-globulin. No reaction with the streptococcal surface antigens was observed (Fig. Io).

\section{DISCUSSION}

In the streptococci used in this study the type antigen was thought to form the outermost layer (preferential formation of antitype antibodies, immunofluorescence). However, no direct evidence was available. A mutant lacking type antigen had different physiological properties (spontaneous agglutination, chain length) which suggest surface differences. Electron micrographs show that in these cells the carbohydrate layer is much less conspicuous (Fig. I $a, b$ ). This was the first direct indication for a localization of the type III antigen on the outermost layer of the streptococcal envelope.

Although some of the type III antigen can be removed from whole bacteria by washing with saline, a significant amount is firmly bound to the cell wall since purified walls of $z_{3}$ III contain a much higher carbohydrate content than $z_{3}$ walls. Trypsin incubation stimulates the liberation of the more firmly bound type III antigens from the walls, suggesting the 

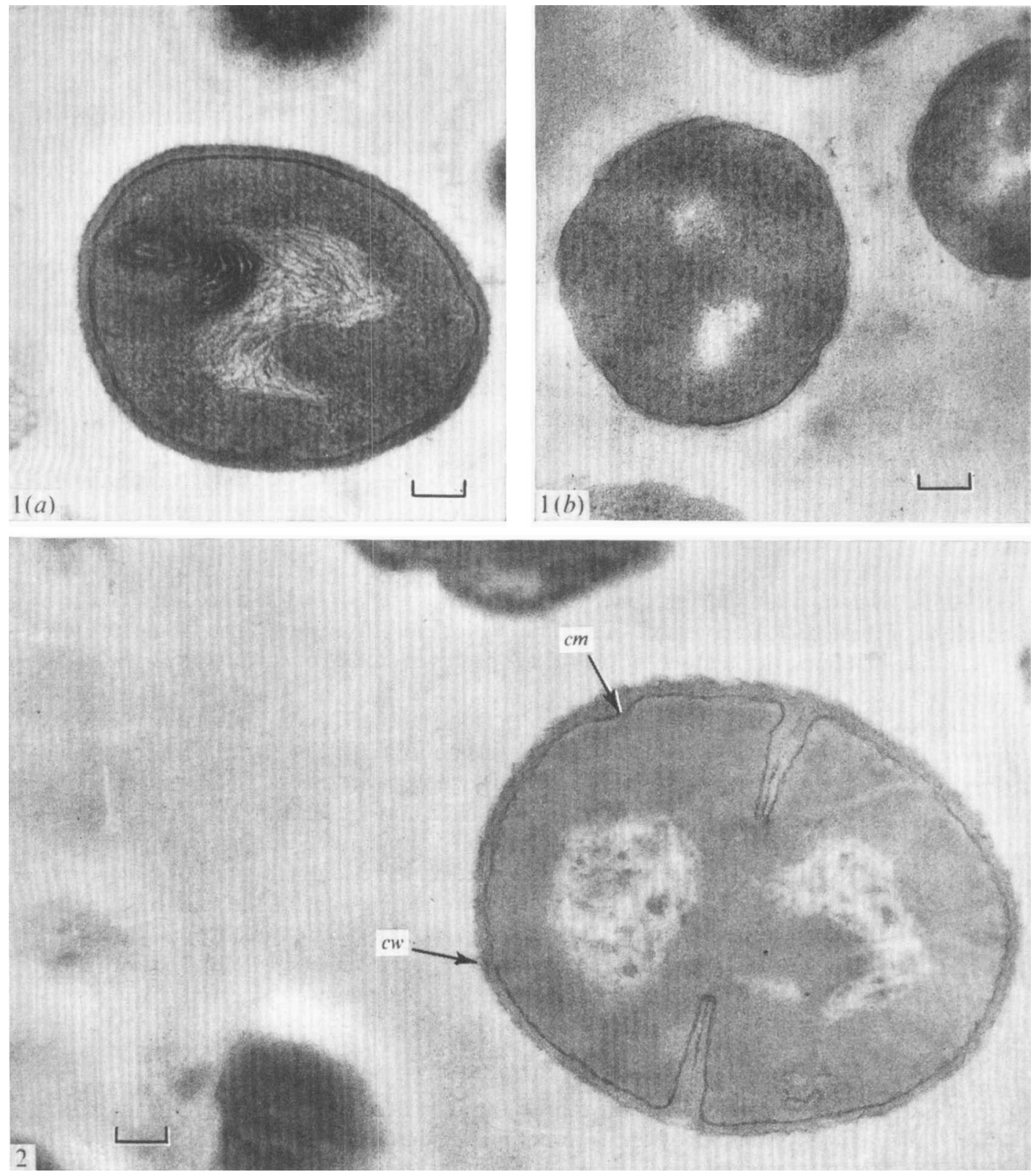

Fig. I. Electron micrographs of streptococcus $\mathrm{Z}_{3} \mathrm{III}(a)$ and a mutant strain lacking the type III antigen $(b)$. The lack of the type III antigen in the wall of the mutant strain resulted in a thinner and less electron-dense appearance. Sections fixed in $\mathrm{OsO}_{4}$ were stained with lead citrate. Scale-bars indicate $0.1 \mu \mathrm{m}$ in all Figures.

Fig. 2. Same organism as Fig. I ( $a$ ), but an older, already dividing, bacterium is shown. $\mathrm{cm}$, Membrane; $c w$, wall, composed of mucopeptide and polysaccharide group and type antigen, without any layered structure. Fixed in glutaraldehyde, unstained. 

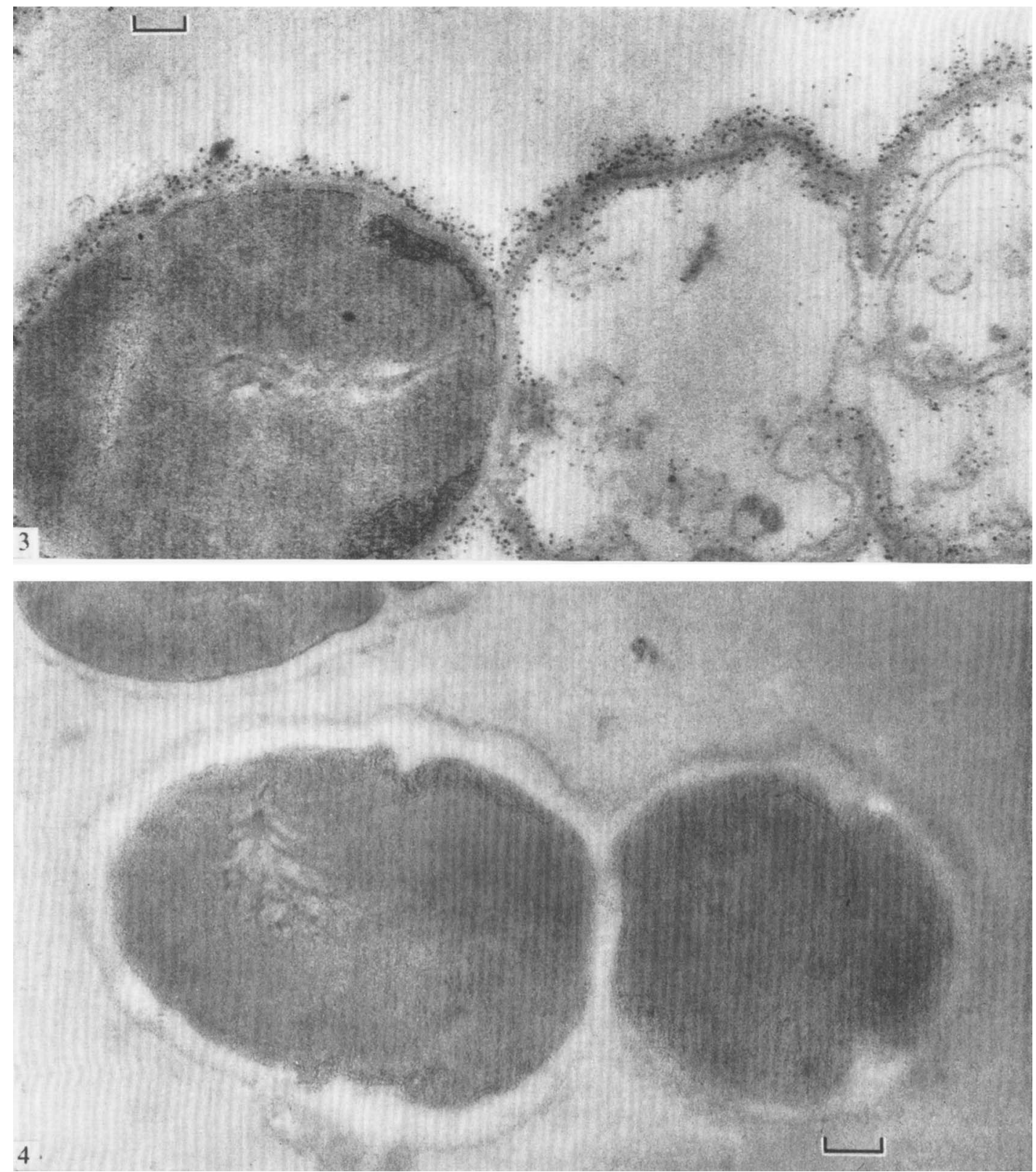

Fig. 3, 4. Electron micrographs of the mutant and parent strain after incubation with ferritin-labelled anti- $Z_{3}$ serum.

Fig. 3. The group antigen appeared as a thin layer located close to the underlying mucopeptide layer.

Fig. 4. The labelled anti- $z_{3}$ serum does not show a visible reaction with the parent strain $z_{3} I I I$. The presence of type III antigen at the outer surface prevents the labelled antiserum from reacting with the underlying group antigen. Fixed in glutaraldehyde and formaldehyde; section poststained with uranyl acetate. 

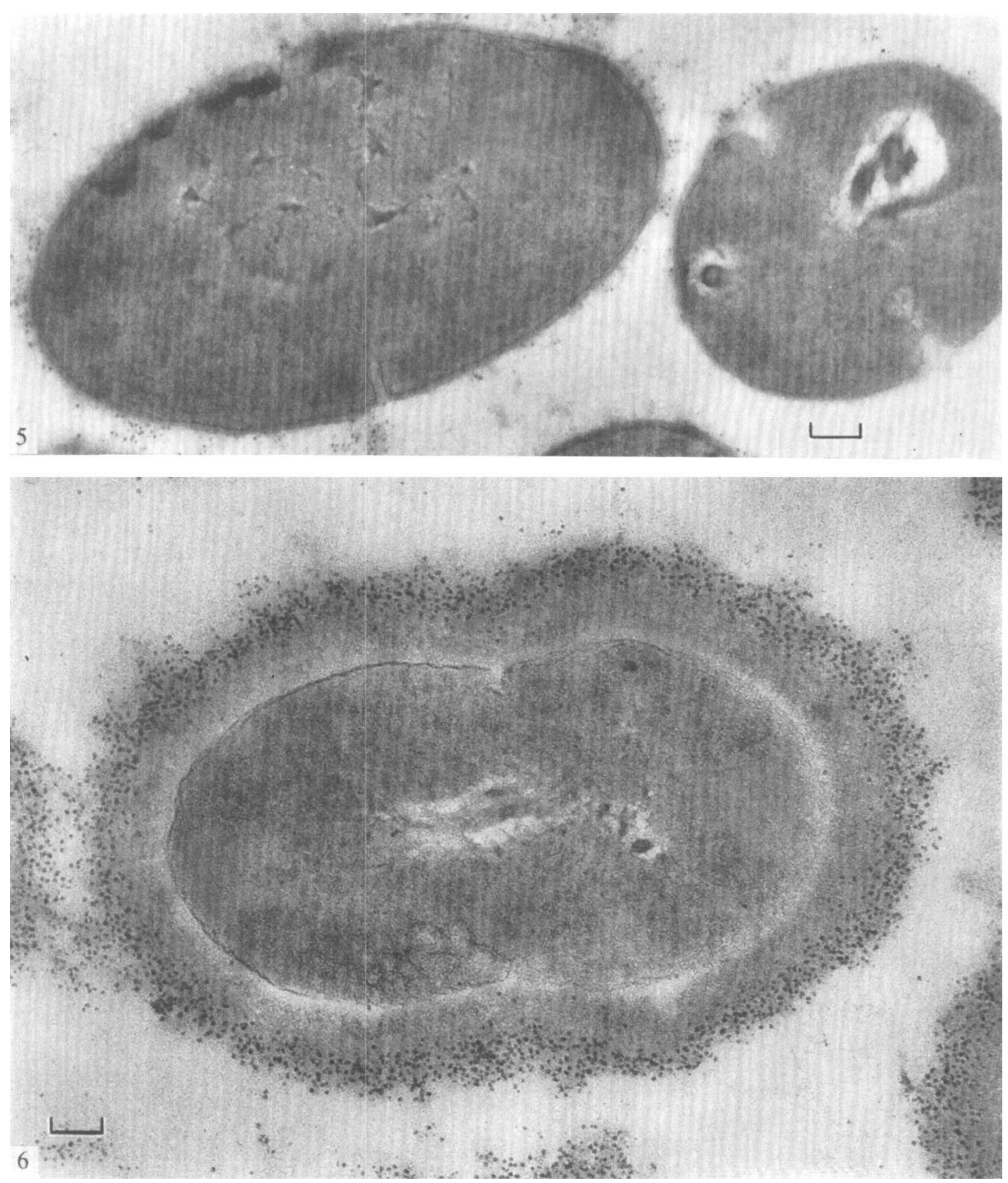

Fig. 5, 6. Electron micrographs of the mutant and parent strain after incubation with ferritin-labelled anti-III serum.

Fig. 5. The mutant strain does not show a clear visible reaction with this serum as compared with the parent strain. Fixation and staining as in Fig. 3.

Fig. 6. Electron micrograph showing the very strong reaction of the parent strain $\mathrm{Z}_{3} \mathrm{III}$ with ferritin-labelled antitype III serum. This micrograph suggests a localization of the type III antigen only at the outermost part of the streptococcal envelope. Fixation and staining as in Fig. 3. 


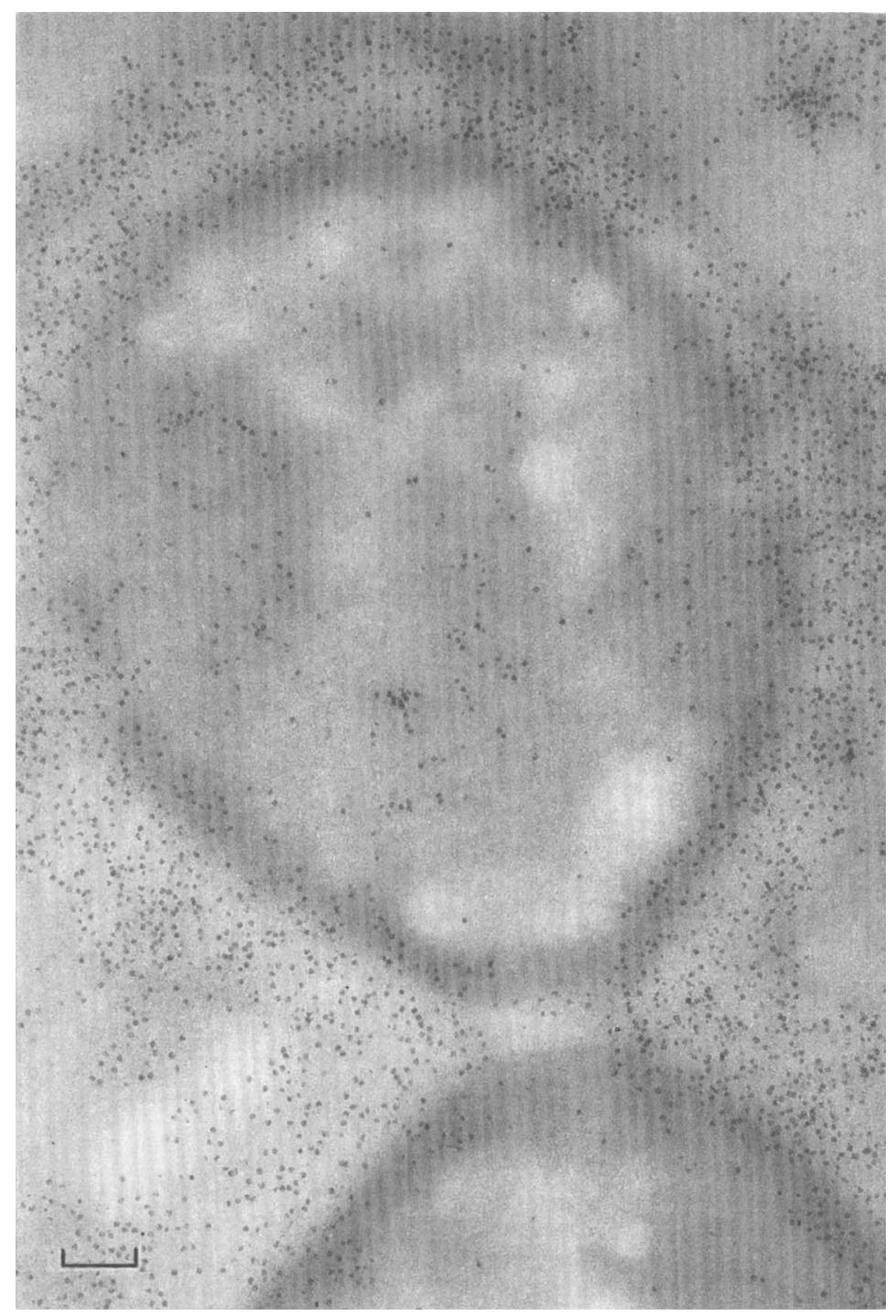

Fig. 7. Electron micrograph of the parent strain $z_{3}$ III after incubation of ultrathin sections with ferritin-labelled anti-III serum. This micrograph shows that the whole envelope of this streptococcus consists of material which reacts with this serum. Note the moderate reaction within the cytoplasmic matrix and near the membrane. Fixation with glutaraldehyde and formaldehyde embedded in GMA, unstained.

involvement of peptide bonds in the binding of this type antigen ( $\mathrm{J}$. Huis in 't Veld \& $\mathrm{J}$. Willers, to be published).

The group $z_{3}$ antigen must be located inside the streptococcal envelope. A mutant strain reacted with ferritin-labelled $z_{3}$ antibodies, whereas the parent strain $Z_{3}$ III failed to do so (Fig. 3,4 ). This is in contrast to observations with fluorescent antiserum where $z_{3}$ III bacteria also gave a positive reaction with fluorescent anti- $Z_{3}$ serum (Willers et al. 1968). Possibly, the type III antigen functions as a diffusion or permeability barrier, permitting the passage 

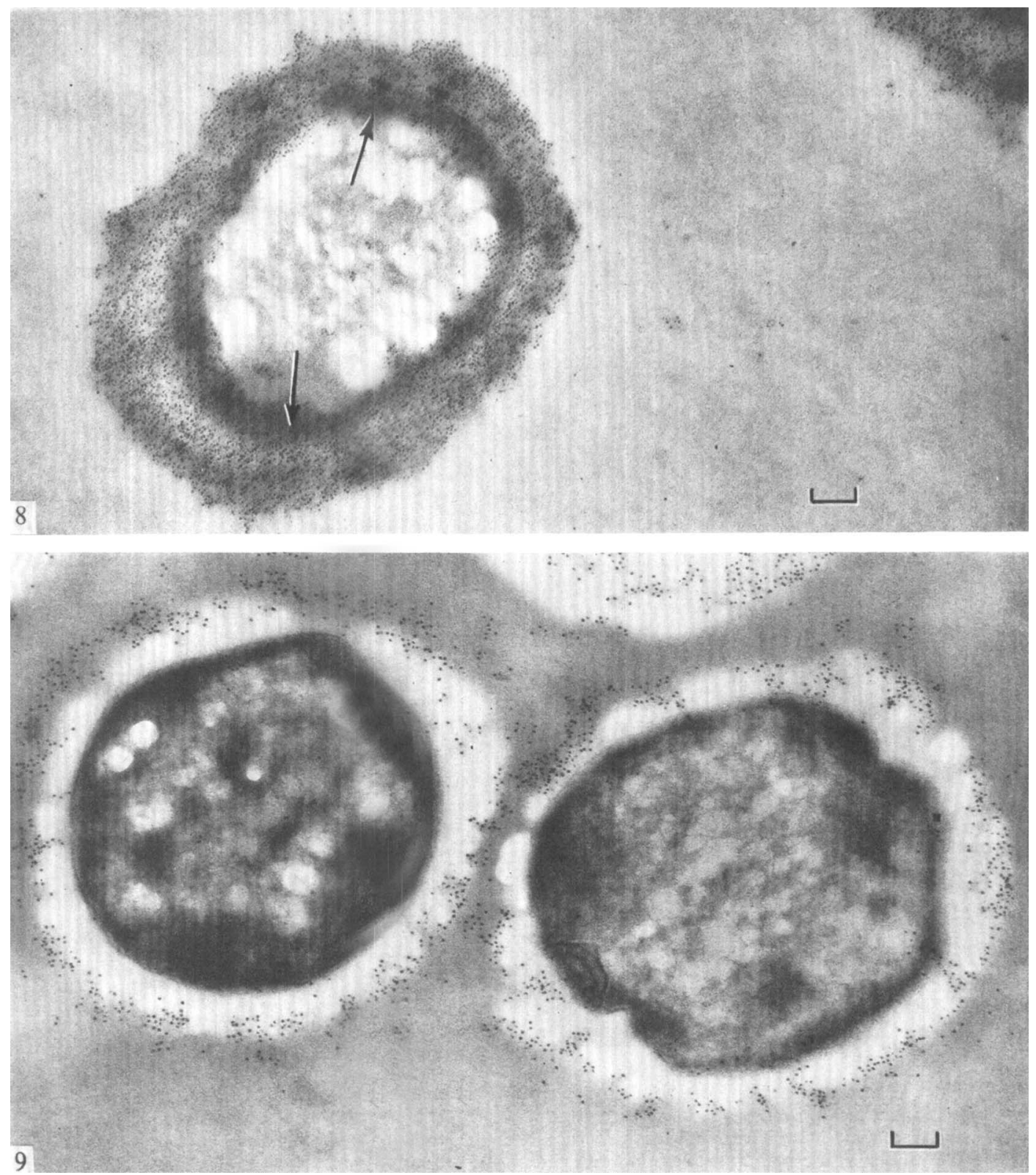

Fig. 8. Ultrathin sections of streptococci, pre-incubated with apoferritin followed by incubation with ferritin-labelled anti-type III serum. This resulted in a decrease of non-specific binding of the ferritin-complex with DNA and RNA, while the positive reaction near the cell membrane is still present. Fixation as in Fig. 7 but sections were poststained with uranyl acetate.

Fig. 9. Blocking experiment showing the high specificity of the labelled antiserum. Pre-incubation of the sections with unlabelled anti-III serum almost completely inhibited the positive reaction because antigen binding sites are already occupied by unlabelled antibodies. Fixation and staining as in Fig. 8. 


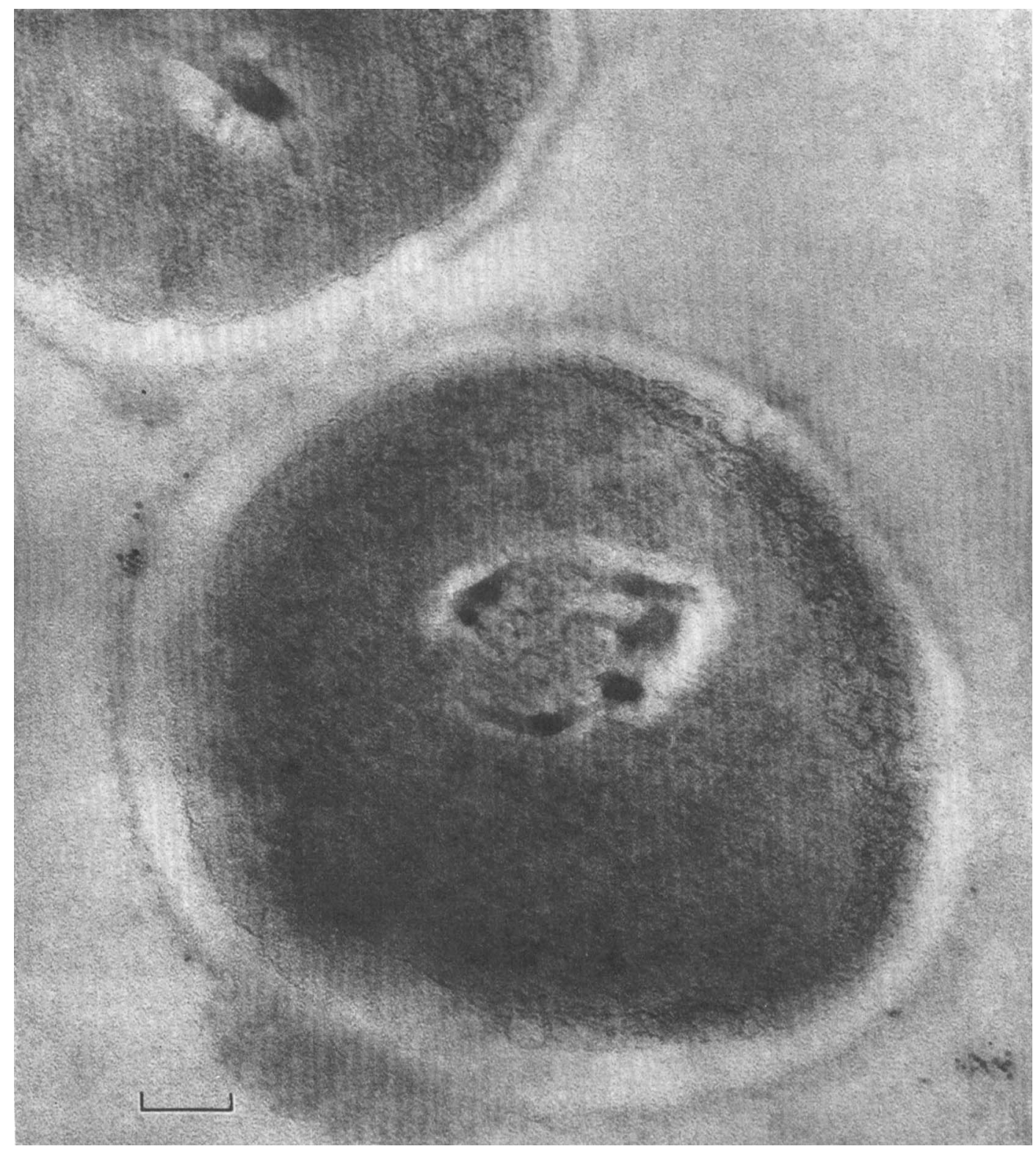

Fig. 10. Control experiment showing the specificity of the ferritin-labelled antisera. Ferritin-labelled non-specific rabbit- $\gamma$-globulin failed to give a visible reaction with the parent strain. Fixation and staining as in Fig. 3.

of fluorescent antibodies $\left(2 \times 10^{5}\right.$ dalton) but impermeable to ferritin-globulin complexes $\left(8 \times 10^{5}\right.$ dalton). The group antigen appeared in this study as part of a rather thin layer firmly bound to the mucopeptide layer. Washing with saline or trypsin did not liberate any detectable serological activity of the group antigen. Only with methods such as hot formamide treatment, could $z_{3}$ activity be extracted from the bacteria. The specific reaction of ferritin-labelled anti- $z_{3}$ serum on the inside of the streptococcal wall (Fig. 3) could indicate 
that the group antigen is also located in or on the cytoplasmic membrane, or that the ferritinlabelled anti- $Z_{3}$ serum cross-reacts with a third membrane-bound antigen, which might be a teichoic acid. Recently a hexosamine-free component with the properties of a lipoteichoic acid, that cross-reacts with anti- $Z_{3}$ serum, was isolated ( $J$. Huis in 't Veld, unpublished work). This component might be found in or in the neighbourhood of the cytoplasmic membrane thus explaining this positive reaction.

The ferritin staining technique failed to give a clear localization of the group antigen in section, probably because of the small amount of the group antigen in these strains.

The mutant strain $z_{3}$ does not react with ferritin-labelled anti-III serum (Fig. 5) though some ferritin particles may be bound at sites where some type III activity is present. $Z_{3}$ III gives a very strong reaction with the ferritin-labelled anti-III serum (Fig. 6, 7).

Particularly in the electronmicrographs shown in Fig. 7 and 8 it can be seen that the whole coat of this streptococcus consists of type III antigen. A very dense localization of ferritin particles, seen in the cytoplasm close to the cytoplasmic membrane, could be a site where the type III antigen is formed or stored.

In this strain type antigen appears to be a capsule-like material but no visible capsule could be detected by negative staining with indian ink.

The authors thank Dr J. J. Geuze, Dr J. M. N. Willers and Dr K. C. Winkler for helpful discussions. The excellent technical assistance of Miss W. E. M. Goedemans is gratefully acknowledged.

\section{REFERENCES}

Kellenberger, E., Ryter, A. \& Séchaud, J. (I958). Electron-microscope study of DNZ containing plasms. II. Vegetative and mature phage DNA as compared with normal bacterial nucleoids in different physiological states. Journal of Biophysical and Biochemical Cytology 4, 67I-678.

LEDUC, E. H. \& Holt, S. J. (I965). Hydroxypropyl methacrylate, a new watermiscible embedding medium for electronmicroscopy. Journal of Cell Biology 26, I37-I 55.

LINSSEN, W. H. G. L. (I97 I). Over de toepasbaarheid van de ferritine-techniek bij de submicroskopische lokalisatie van antigenen. Thesis, University of Utrecht.

OTTENS, H. \& WINKLER, K. C. (1962). Indifferent and haemolytic streptococci possessing group antigen F. Journal of General Microbiology 28, 18I-19I.

Sri Ram, J., Tawde, S. S., Pierce, G. B. \& Midgley, A. S. (i963). Preparation of antibody-ferritin conjugates for immunoelectron microscopy. Journal of Cell Biology r7, 673-675.

Willers, J. M. N. \& Alderkamp, G. H. J. (1967). Loss of type antigen in a type III streptococcus and identification of the determinant disaccharide of the remaining antigen. Journal of General Microbiology 49, 4I-5I.

Willers, J. M. N., Deddish, P. A. \& Slade, H. D. (1968). Transformation of type polysaccharide antigen synthesis and haemolysin synthesis in streptococci. Journal of Bacteriology 96, I 225-1230. 